\title{
Impact of Drug Addiction on Mental Health
}

\section{Wani MA* and Sankar R}

Department of Psychology, Annamalai University, Tamil Nadu, India

\begin{abstract}
Objective: Mental health refers as the individual's adjustment with a maximum of effectiveness, satisfaction happiness and socially considerate behaviour and the ability to face and accept the reality of life. Excess use of drugs largely affects individual's mental health. The present research paper explored the impact of drug addiction on mental health.
\end{abstract}

Method: The present study consists of 60 subjects randomly selected among which 30 were adolescents (15 males and 15 females) and 30 adult's (15 males and 15 females). The P.G.I Health Questionnaire N-I constructed by Varma, Wing and Pershad was used to measure the mental health of drug addicts. The effect of two experimental variables (age and gender) was study on one criterion variable (mental health). For data analysis mean and two way analysis of variance (ANOVA) were applied.

Results: The results revealed that age and gender have significant effect on mental health of drug addicts. Also adults and female addicts show better mental health than adolescents and male addicts. The obtained $F$ ratio was found significant at 0.01 level of significance.

Conclusions: On the basis of our findings it is concluded that age and gender are the influential factors in mental health.

Keywords: Mental health; Age; Gender

\section{Introduction}

Health is the level of utilitarian or metabolic effectiveness of a living being. In humans, it is the general state of a man's brain, body and soul, normally intending to be free from sickness, harm or agony. It is a condition of complete physical, mental, social wee being and not just the nonattendance of malady or illness [1].

The term mental health alludes to cognitive or enthusiastic prosperity of a person. It is about how individuals think, feel and act. Mental health is a condition of prosperity in which each individual understands his or her own particular potential, can adapt to the typical hassles of life and can make a commitment to his or her community (WHO). Mental health is "enthusiastic, behavioral, and social development or ordinariness; the nonappearance of a mental or behavioral issue; a condition of mental prosperity in which one has accomplished a palatable mix of one's instinctual drives satisfactory to both oneself and one's social milieu; a proper equalization of affection, work, and recreation interests" (Med vocabulary's therapeutic lexicon).

A drug alludes to any substance that could achieve an adjustment in the biological function through its synthetic activities [2]. Drug is a substance that alters observations, cognition, mood, behaviour and generally behaviour and general body capacities) [3].

Addiction is one of the socio-psychological issues of the current global community [4]. Addiction is an interminable state in which a man expends sedates over and over which prompts steady changes in his behavior, feelings, and thinking in which the individual loses his/her control and damages him/her or others [5]. Drug addiction alludes to physiological compulsion and psychological dependency. It is incessant and ongoing utilization of any medication or compound substance without medical prescription that alters the physical and mental states.

Drug addiction causes different physiological, organic and also psychological problems, distinctive sort of drugs and their items cause diverse issues like stimulant and hallucinogenic drugs produce mental illness with suspicions, intemperate fears, mood disorders and depression. Narcotics and liquor damage the liver, stomach, brain and nerves which results memory loss, restlessness and so forth. Essentially cannabis items likewise prompt emotional instability or a general loss of enthusiasm among clients. Drug dependence is curse which influences the client as well as cause physical and enthusiastic trouble in the family.

In present days no part of the world seems to be free from the scourge of drug trafficking and drug addiction. Millions of drug addicts, everywhere throughout the world, are driving hopeless lives, amongst life and death. Drug abuse in India is as old as somewhere else. From the earliest starting point, cannabis drugs have been being used than soma rasa, dev booty, opium got to be well known, in India during Shivaratri and Holi, everybody, male and female, drinks a beverage made from cannabis leaves and dry fruits. Indeed, even wine is common in our parties, marriage and so forth. Recently a report in Times of India shows children as young as nine years are succumbing to substance misuse [6]. It is exceptionally stunning that Indian students were found using like nail polish, whitener fluids, shoes polish as drug. The dishonorable thing is they additionally use dirty water of their socks as drug. Use of drugs in India is rapidly growing people with different age group use various types of drugs which is a serious cause that is why the Prime Minister Narendra Modi himself called on the youth of India to make India drug free.

Rich source of literature is available that highlights the impact of drug addiction on mental health few of them are mentioned here

*Corresponding author: Wani MA, Ph.D Research Scholar of Psychology, Annamalai University, Tamil Nadu, India, Tel: 04144238 282; Email: mypsyresearch@outlook.com

Received June 19, 2016; Accepted June 23, 2016; Published June 28, 2016

Citation: Wani MA, Sankar R (2016) Impact of Drug Addiction on Mental Health. J Ment Disord Treat 2: 110. doi:10.4172/2471-271X.1000110

Copyright: ( 2016 Wani MA, et al. This is an open-access article distributed under the terms of the Creative Commons Attribution License, which permits unrestricted use, distribution, and reproduction in any medium, provided the original author and source are credited. 
Khushehmehri et al. [7] investigated that addiction to drugs is common among different age groups. They also found that the young are more disposed to drugs. Nagy [8] in his study discovered that adolescents have indicated differential react to episodic drinking. Results revealed that alcohol consumption significantly damaged the brain of both the adults and the adolescents. Lasser et al. [9] investigated that $44 \%$ of the cigarettes smoked have psychiatric or substance abuse disorder. Solowij [10] researched the long term effects of cannabis on the central nervous system. Results uncovered that long term cannabis use (daily or near daily use for 10 years or more) was associated with impairment of selective attention. Fergusson et al. [11] assessed the short term consequences of early cannabis use. They found that youngsters who reported early cannabis use showed early tendencies to delinquency, poor mental health and educational achievement, they are more affiliations with reprobate or substance-using peers and more family dysfunction. Warner et al. [12] uncovered that drug abuse and dependence are more common among men than among women; the sex ratio for drug abuse is closer to equal than that for alcoholism. Mensch and Kandel [13] in their study dropping out of high school and drug involvement found that high school graduates reported significantly more use of cannabis during adolescence than college graduates. Weller et al. [14] led a study on marijuana use and psychiatric illness. They discovered cannabis utilize also co morbid with conduct disorder in children and adolescents and with antisocial personality disorder in adults. Dube and Handa [15] revealed that mental illness among alcohol users is significantly low than those who take other drugs. Results showed that psychotic use more drugs than neurotic and normal people [16-18].

\section{Methodology and Design}

\section{Problem}

To study the impact of drug addiction on mental health

\section{Objectives}

1. To find the effect of age on mental health of drug addicts

2. To find the effect of gender on mental health of drug addicts

3. To find the interaction effect between age and gender on mental health of drug addicts

\section{Hypotheses}

1. There would be no significant difference found between the mean scores of mental health of adolescent and adult drug addicts.

2. There would be no significant difference found between the mean scores of mental health of male and female drug addicts.

3. There would be no significant interaction found between age and gender of drug addicts

Variables: In the present study the effect of two experimental variables (age and gender) was found on one criterion variable (mental health).

Samples: The present study consist sample of 60 drug addicts selected through randomly sampling method. These 60 samples were equally divided into two groups (adolescent and adult). Further these two groups were divided into two more groups (male and female).

Measuring tool: P.G.I Health Questionnaire N-I constructed by S.K Varma, N.N. Wing and D. Pershad was used by the investigator for the measurement of mental health of addicts. The questionnaire consists of 38 Items (16 items in Area-A) and (22 items in Area-B). The reliability of the test was measured by test-retest and split half methods and was found significantly high ( 0.88 and 0.86 respectively). The Area-A and Area-B was scored as 1 and the number of cross from both Area-A and Area-B was scored as 0 .

\section{Results}

The current study mainly strived to investigate the effect of age and gender on mental health of drug addicts. The data was analyzed to see the significance of the main as well as interaction effects. The obtained raw data of two main variables therefore age and gender were designed as $A$ and $B$ respectively. The two levels of effect of age on mental health were designed as adolescents $\left(A_{1}\right)$ and adults $\left(A_{2}\right)$ and the two levels of effect of gender on mental health were designed as male $\left(B_{1}\right)$ and female $\left(B_{2}\right)$ respectively. All obtained scores were arranged in tabular form. Mean and two way analysis of variance (ANOVA) was applied to saw the main as well as interaction effects. Results are given in tables (Tables 1-3, Graphs 1 and 2).

\section{Discussion}

The results of present study demonstrated that both the independent variables affect the mental health of drug addicts. The significant differences were found between the mean scores of adolescents and adults. The mean score of adolescents $\left(A_{1}\right)$ were found 20.13 and adults $\left(\mathrm{A}_{2}\right) 24.67$ respectively. On the basis of our results we can say that adult

\begin{tabular}{|c|c|c|c|}
\hline $\begin{array}{c}\text { Age of drug } \\
\text { addicts }\end{array}$ & N & Total scores & Mean (X) \\
\hline Adolescents & 30 & 604 & 20.13 \\
\hline Adults & 30 & 740 & 24.67 \\
\hline
\end{tabular}

Table 1: Showing mean scores of age of drug addicts.

\begin{tabular}{|c|c|c|c|}
\hline Gender of drug addicts & N & Total scores & Mean $(\overline{\mathbf{X}})$ \\
\hline Male & 30 & 560 & 18.67 \\
\hline Female & 30 & 784 & 26.13 \\
\hline
\end{tabular}

Table 2: Showing mean scores of gender of drug addicts.

\begin{tabular}{|c|c|c|c|c|c|}
\hline $\begin{array}{c}\text { Sources of } \\
\text { Variation }\end{array}$ & $\begin{array}{c}\text { Sum of } \\
\text { Scores }\end{array}$ & $\begin{array}{c}\text { Degree of } \\
\text { freedom }\end{array}$ & Mean Score & F. Ratio & P \\
\hline $\begin{array}{c}\text { (A) Age of } \\
\text { Addicts }\end{array}$ & 308.26 & 1 & 308.26 & 8.76 & $>0.01$ \\
\hline $\begin{array}{c}\text { (B) Gender } \\
\text { of addicts }\end{array}$ & 836.26 & 1 & 836.26 & 23.77 & $>0.01$ \\
\hline $\begin{array}{c}\text { Interaction } \\
\text { effect (AB) }\end{array}$ & 144.09 & 1 & 144.09 & 4.09 & $>0.05$ \\
\hline $\begin{array}{c}\text { Within group } \\
\text { error }\end{array}$ & 1969.79 & 56 & 35.17 & 0 & \\
\hline
\end{tabular}

Table 3: Summary table of analysis of variance.

\section{Mean Scores}

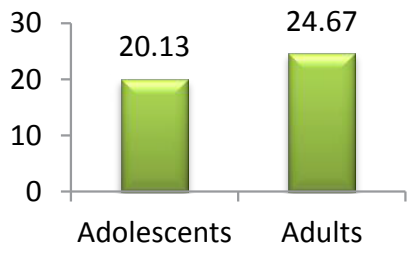

Graph 1: Showing graphical representation of mean scores of age of drug addicts. 


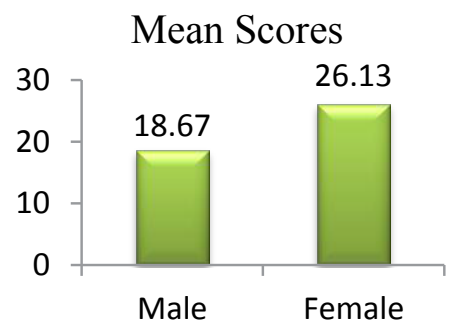

Graph 2: Showing graphical representation of mean scores of gender of drug addicts.

addicts have good mental health than adolescent's addicts. Significant differences were also found between the mean scores of male and female drug addicts. The mean scores of male subjects $\left(B_{1}\right)$ were found 18.67 and female subjects $\left(B_{2}\right)$ were found 26.13. This findings show that female addicts have good mental health than male addicts.

A close look at the ANOVA table indicates that the value of "F" ratio of the first independent variable age is 8.76 , df $1 / 56$ exceeds high than the critic value given in the table at 0.01 level of significance. This leads us to conclude that age is an influential variable is respect of mental health of drug addicts. Therefore our first hypothesis "there would be no significant difference found between the mean scores of mental health of adolescent and adult drug addicts" is rejected. Our findings bear some similarities with those of previous studies like Khushehmehri et al. [7] and Nagy [8]. While taking about the second independent variable i.e. gender the obtained " $F$ " ratio 23.77 , df $1 / 56$ also exceeds high from the critical value at 0.01 level of significance, it means gender is also an infantile variable in respect of mental health of drug addicts therefore our $2^{\text {nd }}$ hypothesis "there would be no significant difference found between the mean scores of mental health of male and female drug addicts" is also rejected. Warner et al. [12] revealed that drug abuse and dependence are more common among men than among women. Thus on the basis of our findings we can say that both age and gender have a great impact on the mental health of drug addicts.

\section{Interaction effect}

The table of ANOVA indicates that the " $\mathrm{F}$ " ratio for the interaction effect $(\mathrm{AB})$ age and gender of drug addicts was found 4.09; df $1 / 56$ is significant at 0.05 level of confidence. This leads us to conclude that both age and gender of addicts slightly affect the mental health of the drug addicts. Therefore the hypothesis "there would be no significant interaction found between age and gender of drug addicts" is rejected hence we can say that there is significant interaction between the age and gender of addicts.

\section{Conclusion}

To sum up, taking into account the results of the current study, we might conclude that age and gender of drug addicts is the significant factors in mental health.

\section{References}

1. World Health Organization (1986) Constitution of the World Health Organization Geneva: WHO.

2. Okoye NN (2001) The adolescents and hard drugs: A psychological concern in R.U.N.

3. Balogun SK (2006) Chronic intake of separate and combined alcohol and nicotine on body maintenance among albino rats. Journal of Human Ecology 19: $21-24$

4. Flora K, Stalikas A (2012) Factors affecting substance abuse treatment in Greece and their course during therapy. Addictive Behaviors 37: 1358-1364.

5. Crews FT, Zou J, Qin L (2011) Induction of innate immune genes in brain creates the neurobiology of addiction. Brain, Behavior, and Immunity 25: 4-12.

6. Pandit A (2015) Shocking finds, even 9-year-olds are taking drugs: report. The Times of India (Delhi).

7. Khushehmehri G, Taheri E, Tehrani H, Fatin S (2010) Knowledge of and attitude toward ecstasy among the university students of Tehran scientific applied higher education. Iranian Journal of Medical Sciences 8: 124-133.

8. Nagy J (2008) Alcohol related changes in regulation of NMDA receptor functions. Current neuropharmacol 6: 39-54.

9. Lasser K, Wesley BJ, Woolhandler S, Himmestein DU, McCormick D, et al (2000) Smoking and mental illness: A population-based prevalence study. Journal of the American Medical Association 284: 2606-2610

10. Solowij N (1998) Long-term effects of cannabis on the central nervous system.

11. Fergusson DM, Lynskey MT, Horwood LJ (1996) The short term consequences of early cannabis use. Journal of Abnormal Child Psychology 24: 499-512.

12. Warner LA, Kessler RC, Hughes M, Anthony JC, Nelson CB (1995) Prevalence and correlates of drug use and dependence in the U.S. Arch Gen Psychiatry 52: $219-229$.

13. Mensch BS, Kandel DB (1988) Dropping out of high school and drug involvement. Sociology of Education 61: 95-113.

14. Weller RA, Halikas JA (1985) Marijuana use and psychiatric illness: A follow-up study. American Journal of Psychiatry 142: 848-850.

15. Dube KB, Handa SK (1971) Drug use in health and mental illness in an Indian population. Br J Psychiatry 118: 345-348.

16. Liechti MEA, Gamma, Vollenweider FX (2001) Gender differences in the subjective effects of MDMA. Psychopharmacology 154: 161-168.

17. Okonkw, Okoye RO, The Nigerian Adolescent in Perspective. A Publication of the Nigerian Society for Education.

18. Tedstone DD, Moran R, Kartalova OY (2008) Psychological distress, mental health problems and use of health services in Ireland. Dublin: Health Research Board, Health Research Board 73 Lower Baggot Street Dublin 2 Ireland. 